\title{
Towards a digitalize economy: The Impact of Training on the Performance of Public Sector IT firms in Africa
}

\author{
Frank Febiri, ${ }^{*}$, and Miloslav Hub ${ }^{1}$ \\ ${ }^{1}$ University of Pardubice, Faculty of Economics and Administration, Pardubice Czech Republic
}

\begin{abstract}
Research background: The widespread adoption of technological advances, such as ICT-enabled infrastructure is becoming the new norm for most African countries. The quest to achieve a digitalized Africa has fuelled public sector IT firms to embark on staff training to enhance their productivity.

Purpose of the article: The present study seeks to examine the influence of such training on public sector IT performance.

Methods: The study uses 70 employees from the public sector IT firm, sampled from LinkedIn professional platform. Primary source of data; mainly the questionnaire was used to gather responses. Statistical Package for Social Sciences (SPSS) was used to analyse the gathered data. Using the correlation coefficient, regression, independent and paired sample test, hypotheses were tested.

Findings \& Value added: The paired sample t test revealed that after training, there was a significant difference in the scores of the IT firm productivity PRO1 $(\mathrm{M}=19.97, \mathrm{SD}=1.88)$ and $\mathrm{PRO} 2(\mathrm{M}=21.77, \mathrm{SD}=$ $1.94), t(-5.00)=69, p<0.05$. There is no significant difference in the scores of male staff $(M=21.80, S D=1.93)$ from those of the female staff $(M=$ $21.70, \mathrm{SD}=1.98), \mathrm{t}(1.95)=68, \mathrm{p}=0.846$ as indicated by the independent sample $t$ test. The relationship between training organizational performance is positive $(\mathrm{r}=0.52, \mathrm{n}=70, \mathrm{p}<0.05)$ while the regression technique shows a positive effect $(b=0.19, \mathrm{p}<5 \%)$ between staff training and IT firm productivity.
\end{abstract}

Keywords: staff training; productivity; information technology; organizational performance

JEL Classification: $E 24 ; M 53 ; P 46 ; P 47$

\footnotetext{
${ }^{*}$ Corresponding author: febirifrank@,upce.cz
} 


\section{Introduction}

Employee training is one of the most important strategies for enhancing effective organizational performance while also promoting the organization's stability index. Abdullahi (2018) defined training as a process that equips individuals with the necessary skills, knowledge, and understanding of the organization's objectives. Training is a systematic procedure that teaches people how to be more productive at work by adjusting their behaviour to attain effective performance, knowledge and skills acquired through learning experience Khawaja \& Nadeem (2013). By continuing to view the interests of employees and the organization, training is crucial in attaining the organization's objectives Kum et al (2014).

Employee perceptions of training have a stronger impact on an organization's success. Employee satisfaction with the organization's training policies will have a beneficial impact on the organization's productivity. Some perceive training and development as a waste of time and resources that could have been better spent on the production of profit-generating goods and services. The worry that an employee will leave the company after training can have an impact on employee training, making it unplanned and unsystematic Diamantidis \& Chatzoglou (2019).

Some Human Resource Departments' procedures and processes for identifying employees who require training are concerning. Employees, for example, may attend training for personal reasons such as enrichment, preparation for other positions in other organizations, power play/politics, or because he or she knows the person in charge of training, rather than because there is a skill gap that needs to be filled through training. In many cases, the Human Resource Department does not analyse training needs Diamantidis \& Chatzoglou (2019). The criteria for selecting employees for training should be systematic and unbiased. It must adhere to a set of guidelines to ensure that the appropriate applicants are sent for training, which will have a favourable impact on the organization's performance. The study of employee development has come up several times. The purpose of this study is to provide answers to important questions. Should companies invest in employee training ? As a result, the study establishes the following objectives.

\subsection{Purpose of the study}

- To evaluate the effects of training on the employees

- To examine the relationship between employee training and firm performance

- To determine if employee training has a significant difference on male and female staff

- To examine the impact of training on the performance of the firm

\subsection{State of hypothesis}

- H0 : There is no significant relationship between employee training and firm performance

- Ha : There is a significant relationship between employee training and firm performance

- H0 : Training outcomes in male employees does not differ significantly from female staff

- Ha : Training outcomes in male employees significantly differs from that of female staff

- H0 : There is no significant impact of training on the performance of the firm

- Ha : There is a significant impact of training on the performance of the firm

Expectations are that the outcome of this study will outline the need for training, and identify ways by which staff training improves the organizations and employees. The remainder of the paper is laid out as follows : The literature review is done in section two, and the methodology is done in section three. The discussion of the results is documented in section 4, while the conclusion and recommendations are documented in section 5. 


\section{Literature Review}

\subsection{Human Resource Management Theory}

Raymond Miles created the theory of human resource management in 1965. It suggests that the labour force has untapped potential. Miles claimed that every person enters a company with a variety of resources that can be used by management to boost overall productivity. This comprises physical energy and skills, as well as self-direction, competences, and creativity, all of which help the company maximize employee performance. The manager's main responsibility is to focus on regulating and directing personnel, as well as making key decisions based on the organization's human resource skills and capabilities. Communication between the employee and the company is becoming increasingly important. It should also promote inclusivity in decision-making and involvement. It went on to say that most businesses have underutilized people resources and that participation is encouraged in order to improve organizational performance and productivity Gentzkow \& Kamenica (2016).

Employee training is an important approach for improving proper and effective firm performance while also ensuring and promoting the firm's stability. If the company wants to achieve its objectives in the most cost-effective manner, it must put up effort and invest time and money in personnel training and education.

Also, the idea is predicated on the notion that education does, in fact, ensure employee retention while accounting for learning transfer in businesses. This raises the issue, "Does the length of education and training guarantee the employee's retention in the organization?" Certainly, this concept is ideal, yet it is debatable in certain organizational contexts. A highly skilled worker might as well look for a higher-paying position. This idea is significant to the research because the organization must recognize that the people at their disposal are untapped resources who require training and development in order to perform at their best and accomplish corporate goals. As a result, firms must devote significant resources to staff training and development, utilizing a range of tactics in order to maximize the resources available to them and so increase the organization's performance Diamantidis \& Chatzoglou (2019).

\subsection{Training, and impacts on Employees}

Employers rarely take into account their employees' feelings about skill development. As a result, Jansen et al (2016) argue that traditional corporate organizations are heavily influenced by military management styles, owing to the fact that armies are the largest and almost certainly the oldest human organizations. Fong, Y. F., \& Li, J. (2016) identified capital development as a reason businesses require their employees to learn new skills on a regular basis. Organizations spend millions modernizing their plants and equipment but very little on human capital development. Employees are a valuable asset to a company, but employers are more concerned with meeting deadlines and increasing profits than with developing employees' talents, which could hinder their effectiveness. Even if the company is still productive, the focus should be on the employees' dedication, commitment, and loyalty. Upto-date equipment will not be used optimally if personnel do not receive ongoing training. Lounsbury, M., \& Beckman, C. M. (2015) and Mudambi, R., \& Puck, J. (2016) also support this position.

Mozael, B. M. (2015) and Okeke-Uzodike, O. E., \& Chitakunye, P. (2014) identified Morale Development as a benefit accrued to employee training. The more competent the workforce, the easier it will be for the entire organization to respond to changes in demand for its products and services in the domestic and worldwide markets. Employees are sometimes hesitant to adapt to change because of the uncertainty involved, but one of the 
goals of the Capabilities Development is to improve the skills of the workforce by increasing investment in education and training in the labour market. Most people associate employee development with intrusive all-day group training sessions. However, Kelly, B. T., Pruitt, S., \& Su, Y. (2019) noted that unfortunately, this hated approach to employee development is the polar opposite of how it should take place and feel to employees. Employee development can take numerous forms, including training, assessment, educational programs, and even feedback.

Performance analysis, generic approaches, and competency evaluation are three methodologies used to determine needs, according to Oseifuah, E. K. (2013). Mansoor, Shah, $\&$ Tayyaba, (2015) conducted a survey to determine the impact of training and development on company performance. Quality and cost were the intermediary human resource responsibilities. About 290 of the 600 questionnaires issued were returned, with 278 being used in the study. The relationship between growth and training and the organization's performance was shown to be beneficial. The aim of the personnel to leave the organizations mediated this result.

A survey on the effects of training on company performance was conducted by Sohrabi et al (2018). The goal of the study was to look into the impact of training on individual employee performance, with the idea that a cumulative advantage of individual performance would lead to exponential performance. The study looked into microfinance banks and chose three (3) at random for the investigation. The study's data came from 304 participants who were identified utilizing the Taro Yamane sample size determination technique. Inferential and descriptive statistics were applied to the data acquired. Knowledge, staff competence, and ability generated from development and training all have a major impact on a company's production, according to the study. Further research revealed that training had an impact on employee dedication to the company.

Quadros and Misango (2017) conducted another study to look into the impact of training on company performance. The research was carried out using a case study method. This strategy was chosen in order to obtain sufficient information from the participants. The research tool was a questionnaire, which was created to capture the goals. About 80 employees were chosen from firms as part of the study's sample frame. The data was analysed using a quantitative technique. Bar charts, frequency tables, pie charts, and percentages are examples of descriptive statistics. The study found that $100 \%$ of those who participated in training reported positive outcomes. The results also revealed that 93.8 percent of the managers reported significant improvements as a result of the training. According to the findings, businesses should take suitable measures, such as training, to equip their staff so that they can provide quality services.

\section{Research Method}

The present study adopts multiple methods of data analyses to analyse the objectives. Sukumar et al (2020) explained that when robustness is the key interest of the researcher, it was necessary to consider a mix of methods. A study outlay or design presents the type of data to be gathered, approached to be used, the measurement of different variables, and the method to be adopted for analysis of data. This present research adopts a set of descriptive and inferential statistics to advance the discussion on the impact of training on the key indexes of the firm including performance.

\subsection{Population of the study}

The questions scheduled by this study are to be answered by employees from Information Technology firms from various African countries. To this end, it considers using IT 
professionals and employees in the labour force. A properly conceived research instrument was forwarded to professionals who have a functional online presence on LinkedIn platform. The platform accommodates different IT experts from the various spheres of life. To allow for a wide participation, the researcher distributed consent forms to the participants on LinkedIn. The content of the consent contained the objectives of the study, the need for their participation and need to respond correctly and precisely to the information in the questionnaires. Over 100 questionnaires were distributed. However, about 70 respondents successfully filled and completed the survey.

\section{Results and Discussion}

The gathered data are collated, entered, coded into the Statistical Packages for Social Scientists tool (SPSS Version 23). The combination of descriptive and inferential statistics was used mainly for the analysis. The objectives of the study are analysed with different techniques. For objective 1; The profile of the respondents is done by using the descriptive statistics, which includes percentages, mean, mode and frequency. For objective 2, examine the influence of employees' training on the improvement of the employees, the regression model would be used to analyse this objective. In objective 3, training outcomes in males and females was examined using the independent $t$ test while objective 4 , the effect of employee training on the performance of the organization is done using the paired sample $t$ test and for robust, the regression analysis was used. For the essence of this study, a model that expresses organizational performance as a relation of staff training, and development is written as;

$$
\mathrm{FP}=\beta 0+\beta 1 \mathrm{STrit}+\varepsilon .
$$

where FP $=$ Firm performance (measured by the revenue) while STr $=$ IT Staff Training.

Out of 70 respondents, 46 of the respondents representing $66 \%$ were men while 24 respondents representing about $34 \%$ were female. The findings suggest that the majority of the employees sampled are men. This result is as expected since men form the bulk of the working force in the IT sector of most IT firms across Africa (Mansoor et. Al. 2015).

Again, with the distribution of respondents according to firm type, Out of the 70 respondents, $45(64 \%)$ of the respondents are from private firms while $25(36 \%)$ of them are from the public firms.

According to the survey result, $10 \%$ (7) of the respondents are aged below 20 years. The proportion of sample population who are within 21 to 30 years is $22 \%(16)$ and another $31 \%$ (22) of the population ages between 31 to 40 (16) years respectively. $22 \%$ (16) and $12 \%$ (9) of the population have their ages to be greater than 41 to 50 years and 51 years and above respectively. Only a few proportion of the sample size is advanced in age. The above result suggests that the firm is predominantly that of young and vibrant employees. By implication, this means that given the right resources for production, the workforce has the required vigor and energy for work.

The data collected shows that $4(6 \%)$ of the respondents have had below 5 years of experience. $20(29 \%)$ have had about 6 - 10 years' experience. (27) $39 \%$ of the respondents have had about $11-15$ years. $10(14 \%)$ have had $16-20$ years' experience. About $10(14 \%)$ have had over $16-20$ years of experience. $4(6 \%)$ and $5(7 \%)$ of the respondents have had 21 - 25 years of experience and above 25 years respectively. The results suggest that most respondents have good years of experience. One that is ideal for a study of this nature.

A greater proportion of the employees surveyed are technical staff representing $42(60 \%)$ of the population. $22(31 \%)$ of the population is mid-level management staff while $6(9 \%)$ of the sampled population is from the top management class. Evidently, the study has a mix of 
employees from different cadres in the firm thus information with regards to the training programme elicited from this survey is deemed as balanced and well rounded.

Out of the 70 respondents $2(3 \%)$ have attended conferences, 3(4\%) have attended seminars, $21(30 \%)$ have attended training institutions, 25(35\%) got study leave while over $19(27 \%)$ went on internship. Evidently, the respondents have had one form of selfdevelopment or the other

Majority of the participants are in support of employee training. The data also shows the outcome of variables on the impact of training on the staff. On the variable "Employee training" improves employee's performance, $0(\%)$ responded strongly disagree. $5(7 \%)$ responded disagree, $8(11 \%)$ are neutral, $12(17 \%)$ agreed while $45(64 \%)$ strongly agreed.

On the variable "Employees gain new knowledge after training", $0(0 \%)$ responded strongly to disagree. $3(4 \%)$ responded disagree, $11(16 \%)$ are neutral, $46(66 \%)$ agreed while $10(14 \%)$ strongly agreed. On the variable "Training increases employee confidence during work", $2(3 \%)$ responded strongly disagree. $9(13 \%)$ responded disagree, $8(11 \%)$ are neutral, 20(29\%) agreed while 31(44\%) strongly agreed.

Evidently, the majority of the respondent agreed that training improves employee's performance, allows for new knowledge to be gained, and increases the confidence of employees. The current result is in line with the finding of Roca, J. D. L., \& Puga, D. (2017) who documented that training leads to workers' efficiency and also with the finding of Panagiotopoulos, G., \& Karanikola, Z. (2017), Conforms with knowledge acquiring benefits which Al Ahbabi et al (2019) had earlier postulated.

On the variable "improves firms' productivity", $0(0 \%)$ responded strongly to disagree. $5(7 \%)$ responded disagree, $8(11 \%)$ are neutral, $21(30 \%)$ agreed while $36(51 \%)$ strongly agreed. On the variable "Reduction of project failures", $0(0 \%)$ responded strongly to disagree. 3(4\%) responded disagree, 12(17\%) are neutral, 38(54\%) agreed while 17(24\%) strongly agreed. Evidently, the majority of the variables all support the fact that training affects the firm positively. The result show that it improves firm performance, reduces projects failure and staff turnover.

Table 1 : Relationship between Staff Training and selected variable of the IT Firm

\begin{tabular}{lcccccc}
\hline & 1 & 2 & 3 & 4 & 5 & 6 \\
\hline Training & 1 & & & & & \\
Performance & 0.525 & 1 & & & & \\
Productivity & 0.515 & 0.226 & 1 & & & \\
Reduce Failure & 0.205 & -0.078 & 0.273 & 1 & & \\
Staff turnover & -0.268 & -0.169 & -0.177 & -0.222 & 1 & \\
Staff Morale & 0.058 & 0.071 & 0.004 & 0.271 & -0.239 & 1 \\
\hline
\end{tabular}

Source : Authors computation using SPSS

Table 1 examines the relationship between staff training and some selected variables. Correlation analysis was used. The test was carried out under the following hypothesis. Null hypothesis (H0): There is no relationship between staff training and the variables. The relationship is as follows; There is a medium and positive relationship between staff training and performance $(r=0.52, n=70, p<0.05)$. Also, productivity relate positively with staff training $(\mathrm{r}=0.515, \mathrm{n}=70, \mathrm{p}<0.05)$ while Reduce project failure and morale also show positive and significant relationship with training $(r=0.205, \mathrm{n}=\mathrm{n}, \mathrm{p}<0.05)$ and $(\mathrm{r}=0.058$, $\mathrm{n}=\mathrm{n}, \mathrm{p}<0.05)$. For staff turnover, the result is negative and significant $(\mathrm{r}=-0.26, \mathrm{n}=70, \mathrm{p}<$ 
0.05). This result implies that as staff training increases, performance, productivity, reduced project failures increases while staff turnover reduces.

Table 2 : Does training Outcome in male staff differ from female staff?

\begin{tabular}{lllllll}
\hline Time & Device & Mean & SD & t & df & Sig \\
\hline \multirow{2}{*}{1} & Male & 21.80 & 1.93 & 1.95 & 68 & 0.846 \\
& Female & 21.70 & 1.98 & & & \\
\hline
\end{tabular}

Source : Authors computation

An independent sample t-test was conducted to compare the mean score of training on male and female employees of the organization. There was no significant difference in the scores of males $(\mathrm{M}=21.80, \mathrm{SD}=1.93)$ and females $(\mathrm{M}=21.70, \mathrm{SD}=1.98), \mathrm{t}(1.95)=68$, $\mathrm{p}=0.846$ (two-tailed). This result implies that the benefits of training programmes on the male gender are the same to the female.

Table 5 : Employee training and the Productivity of the IT Firm

\begin{tabular}{ccccccc}
\hline Time & Device & Mean & SD & t & df & Sig \\
\hline \multirow{2}{*}{1} & PRO1 & 19.97 & 1.88 & -5.00 & 69 & 0.000 \\
& PRO2 & 21.77 & 1.94 & & & \\
\hline
\end{tabular}

Source : Authors Computation using SPSS, 2021

A paired samples t-test was conducted to compare the mean score of training on staff productivity. The test is done in two intervals. The first (PRO1) being before training and the second (PRO2) being after the training. There was a significant difference in the scores of PRO1 $(\mathrm{M}=19.97, \mathrm{SD}=1.88)$ and PRO2 $(\mathrm{M}=21.77, \mathrm{SD}=1.94), \mathrm{t}(-5.00)=69, \mathrm{p}<0.05$ (two-tailed). This result implies that the productivity of the staff increased after training.

Table 6 : The impact of education, training on IT firm productivity

\begin{tabular}{|c|c|c|c|c|c|}
\hline \multicolumn{3}{|c|}{ Regression Statistics } & & & \\
\hline \multicolumn{2}{|c|}{ Multiple R } & 0.771 & & & \\
\hline \multicolumn{2}{|c|}{ R Square } & 0.873 & & & \\
\hline \multicolumn{2}{|c|}{ Adjusted R } & 0.760 & & & \\
\hline \multicolumn{2}{|c|}{ Standard Error } & 1.883 & & & \\
\hline \multicolumn{2}{|c|}{ Observations } & 70 & & & \\
\hline \multicolumn{6}{|l|}{ ANOVA } \\
\hline & $\mathrm{df}$ & $\mathrm{SS}$ & MS & $\mathrm{F}$ & Sig. \\
\hline Regression & 1 & 19.131 & 19.131 & 5.393 & 0.023 \\
\hline Residual & 68 & 241.211 & 3.547 & & \\
\hline \multirow[t]{3}{*}{ Total } & 69 & 260.343 & & & \\
\hline & & Standard & & & \\
\hline & Coefficients & Error & t Stat & P-value & \\
\hline Intercept & 18.257 & 1.530 & 11.935 & 0.000 & \\
\hline Firm Perf & 0.195 & 0.084 & 2.322 & 0.023 & \\
\hline
\end{tabular}

Source : Authors Computation using SPSS, 2021 
Table 6 above shows the impact of employee training on the organization. The Square value is 87 percent implying the model was able to predict the dependent variable. The beta value is $(\mathrm{B}=0.19, \mathrm{P}<5 \%)$. Training has a positive impact on the productivity of the firm. Evidently, as employee training improves, as employees take on self-development programmes, the organizational productivity improves. This shows that employee training is important for organizational performance. The result confirms previous findings by Uzoamaka, E.V. and Innocent. I.E. (2017) and Tiwari, B., \& Lenka, U. (2017). These studies all documented a positive nexus between IT staff training and the firm productivity.

\section{Conclusion and Recommendation}

The current study sought to understand if the company should sponsor the self-development of their employees. Following the result of the analysis, employee training and development has useful implications to the firms and the employee as well. Self-development enhances employee's productivity, IT staff gain new knowhow after training programmes and Training increases employee confidence during work. Evidently, the majority of the variables all support the fact that self-development, training affects the employees positively. Results also show that the majority of the respondents think that training and assisting employees meet targets, assists employees achieve productivity and increases employee confidence during work. Finally, this study presents us with evidence of a significant and positive association between increased firm performance and training. It follows therefore, that all forms of targeted programmes designed to improve the capacity of the staff directly influences their output and the firm as a whole. In view of this, the study proposes that IT firms should institutionalize staff improvement programmes in all departments to allow employees to gain adequate and sufficient skills and proficiency necessary for the requisite performance and qualitative service in record time. Training sessions, study leaves, internships and seminars are parts to achieving the targeted result.

\section{References}

1. Hameed, A., \& Waheed, A. (2011). Employee Development and Its Effect on Employee Performance A Conceptual Framework. International Journal of Business and Social Science, 2(13), 224-229.

2. Abdullahi, M. S. (2018). Effect of training and development on employee's productivity among academic staff of Kano state polytechnic, Nigeria. Asian People Journal (APJ), 1(2), 264-286.

3. Al Ahbabi, S. A., Singh, S. K., Balasubramanian, S., \& Gaur, S. S. (2019). Employee perception of impact of knowledge management processes on public sector performance. Journal of Knowledge Management, 23(2), 351-373.

4. Diamantidis, A. D., \& Chatzoglou, P. (2019). Factors affecting employee performance: an empirical approach. International Journal of Productivity and Performance Management, 68(1), 171-193.

5. Fong, Y. F., \& Li, J. (2016). Information revelation in relational contracts. The Review of Economic Studies, 84(1), 277-299.

6. Gentzkow, M., \& Kamenica, E. (2016). Competition in persuasion. The Review of Economic Studies, 84(1), 300-322.

7. Jansen, J. J., Kostopoulos, K. C., Mihalache, O. R., \& Papalexandris, A. (2016). A sociopsychological perspective on team ambidexterity: The contingency role of supportive leadership behaviours. Journal of Management Studies, 53(6), 939-965. 
8. Kelly, B. T., Pruitt, S., \& Su, Y. (2019). Characteristics are covariances : A unified model of risk and return. Journal of Financial Economics, 134(3), 501-524.

9. Khawaja, J., \& Nadeem, A. B. (2013). Training and Development Program and its Benefits to Employee and Organization: A Conceptual Study. European Journal of Business and Management, 5(2), 243-252.

10. Kum, F.D., Cowden, R. and Karodia, A.M. 2014. The Impact of Training and Development on Employee Performance: A Case Study of Escon Consulting. Singaporean Journal Of Business Economics, and management studies, 3(3), 75-105.

11. Lounsbury, M., \& Beckman, C. M. (2015). Celebrating organization theory. Journal of Management Studies, 52(2), 288-308.

12. Mozael, B. M. (2015). Impact of training and development programs on employee performance. International Journal of Scientific and Research Publications, 5(11), 3742.

13. Mansoor, S., Shah, F. T., \& Tayyaba, A. (2015). Impact of training and development on organization performance with mediating role of intention to quit as human resource quality cost. European Online Journal of Natural and Social Sciences, 4(4), 787-797.

14. Mudambi, R., \& Puck, J. (2016). A global value chain analysis of the regional strategy perspective. Journal of Management Studies, 53(6), 1076-1093.

15. Okeke-Uzodike, O. E., \& Chitakunye, P. (2014). Public sector performance management in Africa: Reforms, policies and strategies. Mediterranean Journal of Social Sciences, $5(26), 85-85$.

16. Oseifuah, E. K. (2013). Activity based costing approach to financial management in the public sector : the South Africa experience. European Scientific Journal, 9(1), 35-53.

17. Panagiotopoulos, G., \& Karanikola, Z. (2017). Training of Human Resources and Job Satisfaction. Global Journal of Human Resource Management, 5(7), 36-45.

18. Quadros, D. V., \& Misango, S. B. (2017). Effects of training on organizational performance: a study of AGGREKO international Nairobi, Kenya. International Journal of Social Science and Economic Research, 2(8), 4316-4334.

19. Roca, J. D. L., \& Puga, D. (2017). Learning by working in big cities. The Review of Economic Studies, 84(1), 106-142.

20. Sohrabi, B., Vanani, I. R., \& Abedin, E. (2018). Human resources management and information systems trend analysis using text clustering. International Journal of Human Capital and Information Technology Professionals (IJHCITP), 9(3), 1-24.

21. Stahl, G. K., \& Tung, R. L. (2015). Towards a more balanced treatment of culture in international business studies : The need for positive cross-cultural scholarship. Journal of International Business Studies, 46(4), 391-414.

22. Sukumar, A., Jafari-Sadeghi, V., Garcia-Perez, A., \& Dutta, D. K. (2020). The potential link between corporate innovations and corporate competitiveness : evidence from IT firms in the UK. Journal of Knowledge Management, 24(5), 965-983.

23. Tiwari, B., \& Lenka, U. (2017). Engaging workforce in downsized firms: scenario of the Indian IT/ITES sector. Industrial and Commercial Training, 50(1), 32-38.

24. Uzoamaka, E. V. \& Innocent. I. E. (2017). Effect of Employees Training on Organizational Performance: A Study of Seven-Up Botlling Company, Enugu State Nigeria. IIARD International Journal of Economics and Business Management, 3(10), 48-63. 